Vol. 20(2011): 217-227.

\title{
Characteristics of dry- and brine-salted salmon later treated with liquid smoke flavouring
}

\author{
Olaia Martinez*, Jesús Salmerón, María D. Guillén and Carmen Casas \\ Departamento de Farmacologia y Ciencias de los Alimentos, Facultad de Farmacia, \\ Universidad del País Vasco (UPV) 01006-Vitoria, Spain. \\ *e-mail: olaia.martinez@ehu.es
}

\begin{abstract}
The use of smoke flavourings for the processing of salmon has begun to substitute traditional smoking methods. This review examines the quality issues associated with salted salmon 'smoked' by this technique along the salting and smoking steps. Firstly, the evidence is examined to determine whether dry or brine salting is better for salmon flesh destined to be treated by liquid smoking. Secondly, influence of liquid smoking on the sensorial, physicochemical and textural characteristics of the flesh are described, as are its effects on potential spoilage organisms.
\end{abstract}

Key-words: Salmon, liquid smoke flavouring, dry and brine salting.

\section{Introduction}

Atlantic salmon (Salmo salar) is an economically and nutritionally important cultured fish species (Dondero et al. 2004). About $40-50 \%$ of farm-reared Atlantic salmon reaches the consumer as traditional cold-smoked gourmet food products (Birkeland and Bjerkeng 2005); indeed, a number of countries have long traditions of producing and consuming smoked food products (Birkeland and Skara 2008).
The process of cold-smoked salmon includes salting and drying before any type of smoking, and the final product typically contains between 2.0-3.9\% salt in the water phase (Bannerman and Horne 2001, Huang et al. 2002; Oenhlenschlager 2007, Bocker, et al., 2008). Salmon thus salted is categorized as "lightly preserved" (Leroi 2010). Salt functions as a flavour enhancer, increasing the perception of the fullness, thickness and sweetness of food (Gallart-Jornet et al. 2007a). It may be added by injection, by dry salting or by brine 


\section{AGRICULTURAL AND FOOD SCIENCE}

Martinez, O. et al. Liquid smoked salmon as affected by salting method

salting, the latter two being the most commonly used in the salmon processing industry (Birkeland and Bjerkeng 2005).

Smoking impregnates high-protein foods with aromatic components. These lend flavour and colour to the finished product as well as playing a bacteriostatic and antioxidant role (Kristinsson et al. 2008). Along the last decades traditional smoking methods have given way to the use of smoke flavourings. Treatment with these flavourings is much cheaper and has a much less toxic effect on the environment (Pszczola 1995, Underwood and Shoop 2007). In addition, their use avoids the formation of polycyclic aromatic hydrocarbons, a drawback of the traditional process (Guillen et al. 1996). Smoke flavourings of different composition are available and can be combined to obtain products with different sensorial qualities (Abu-Ali and Barringer 2007, Gedela et al. 2007).

The optimisation of the individual operations involved in the processing of smoked salmon, i.e., salting, drying and smoking, is important in the economic success of this sector which has small profit margins (Birkeland et al. 2004). This paper summarises the available information on the salting procedures employed and tries to determine whether dry salting or brine salting is better for use with salmon to be smoked with liquid smoke flavourings. Moreover, the most outstanding features imparted by liquid smoke flavouring to salmon flesh after salting by different methods are discussed.

\section{Salting}

The uptake and distribution of salt in fish fillets depends on the salting method used, the species in question, the thickness of the fillet, the fish/salt weight ratio (Gallart-Jornet et al. 2007b,2007c, Bras and Costa 2010), and intrinsic flesh factors such as the composition and structure of the muscle and the rigor condition (Aursand et al. 2009, 2010). Lipids in flesh play an important role as a limiting factor during the salting and drying steps, either replacing the aqueous phase that serves as a vector for transfers during these steps or acting as physical barrier (Cardinal et al. 2001).

When a salt solution or dry salt is used for salting, two main simultaneous fluxes occur: the uptake of salt by the muscle and the loss of water from it (Gallart-Jornet et al. 2007b, Czerner and Yeannes 2010), a consequence of the differences in the osmotic pressure of the muscle cells and the salting agent (Barat et al. 2002). Table 1 shows several salting protocols and their effect in the flesh quality. In dry salting, a water interface is created by the extraction of the intercellular water to the surface of the flesh. In brine salting, however, the products are soaked in a solution which reduces the outward diffusion of water (Rora et al. 2004, Bellagha et al. 2007). The use of dry salt causes fiber shrinkage (Sigurgisladottir et al. 2000, Bocker et al. 2008), the cross-sectional area of the muscle fibers becoming smaller after such treatment than after brine salting. Brine-salted salmon can, however, show a wide variation in muscle fiber size, with some fibers expanding, others shrinking and others still showing no change. This might be an effect of an uneven salt distribution within the muscle.

Montero et al. (2003) reported that differences in protein solubility (sarcoplasmic and myofibrillar fractions) between salmon processed using different salting methods were not significant, and that protein solubilisation was not influenced by the salt level. However, salt is well known to affect the structural proteins of muscle (Larsen et al. 2008) and the changes in rates of salt penetration closely follow changes in the amount of extractable protein (Minh et al. 2011).

Brine salting causes the solubilisation of some of the muscle proteins, which are released into the brine (Unlusaying et al. 2010). Martinez et al. (2005) and Martinez-Alvarez and Gómez-Guillén (2006) indicate that the loss of nitrogenous components during brine salting may be due to the enhancement of protein solubility, a consequence of the increasing salt content of the tissues. Salt-induced protein destruction would be followed by the leaching of protein components into the brine. At the same time, the cations introduced into the flesh might also induce conformational changes and affect protein/water interactions, and hence protein 
Vol. 20(2011): 217-227.

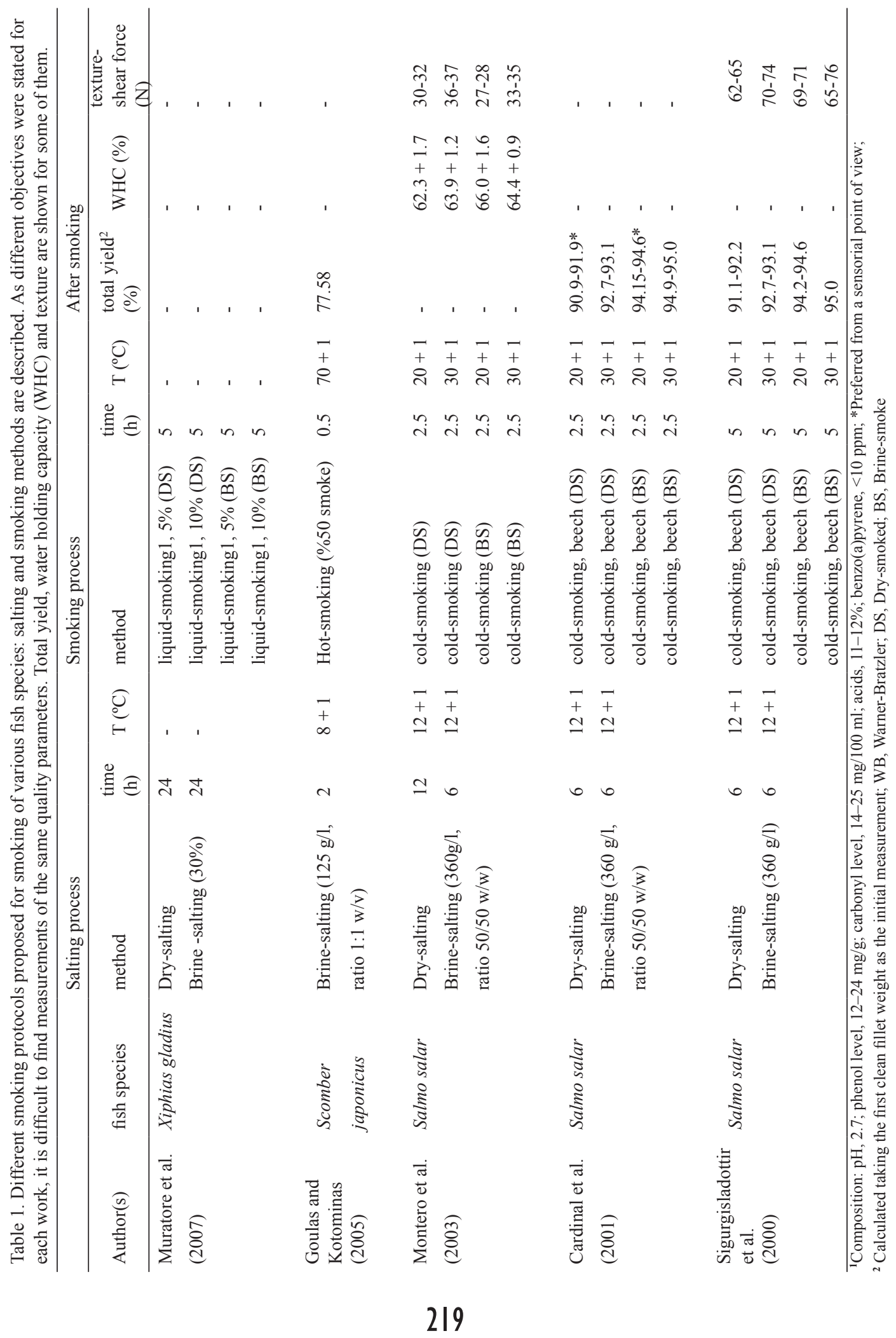


Martinez, O. et al. Liquid smoked salmon as affected by salting method

solubility. Hultmann and Rustad (2004) and Carton et al. (2009) suggest that the conformation of the myofibrillar proteins may change as a result of the increased salt content of the muscle rendering the proteins more susceptible to attack by endogenous proteases.

Birkeland et al. (2004) and Gallart-Jornet et al. (2007b, 2007c) report that fillets subjected to dry salting show a significantly higher total liquid loss than fillets subjected to brine salting. However, brine salting shows great water losses and smaller water phase in protein matrix when saturated brine $(25 \% \mathrm{w} / \mathrm{w})$ is used (Barat et al. 2002). This lead to a lower water holding capacity, comparing with less saturated brines $(20 \% \mathrm{w} / \mathrm{w})$ and important changes in texture (Sannaveerappa et al. 2004, Thorarinsdottir et al. 2004). In fact, Instrumentally measured texture parameters (Force, Area) show an exponential increase with respect to the $\mathrm{NaCl}$ concentration in the liquid phase (Barat et al. 2002). Sigurgisladottir et al. (2000) report the shear force required for cutting dry salted fillets to be lower than that required to cut brine-processed fillets, for certain fish species and in a season dependent way. Nevertheless, most authors (Birkeland et al. 2004, Gallart-Jornet et al. 2007b) describe harder textures in fish treated with saturated brines and even harder for dry-salted fish fillets. Texture of fish is related to the diameter of the muscle fibers: smaller diameters and higher number of fibers give harder textures and larger diameters but less number of fibers, softer (Hatae et al. 1990). The greater reduction of the cross sectional area in dry-salting processes has been suggested as the reason for their firmer texture when comparing them with the not saturated brine-salted ones. However, fish texture in known to be a multifactorial quality in which fiber size is not necessarily the major determinant (Johnston et al. 2006, Morkore et al. 2009).

Cardinal et al. (2001) reported that dry and brine salting have little effect on the sensorial properties of salmon. However, Birkeland et al. (2003) indicate dry salting to be a 'more gentle' curing method that helps retain the intactness of the fillet surface and its colour - important consumer quality criteria. Moreover, Gallart-Jornet et al. (2007b) report drysalted fillets and the more saturated brines salted ones to show significantly greater firmness and less elasticity than low concentrated brine-salted fillets. The same tendency is observed when comparing early and last salting stages with saturated brines. Finally, several authors (Aubourg and Ugliano 2002, Guillen et al. 2004, Goulas and Kontominas 2005, 2007, Yanar et al. 2006, Alfonso and Sant'Ana 2008) report that the contact of the salt with the flesh enhances lipid oxidation. Some studies have shown that the stimulation of lipid oxidation occurs through the activation or iron. Sodium ions displace the iron from macromolecules such as myoglobin, increasing the availability of the latter for the catalysis of lipid oxidation (Thiansilakul et al. 2010, Kashiri et al. 2011). Several authors indicate that brine salting offers the major advantages of preventing rancidity by precluding contact with the air and of affording a higher weight yield caused by the uptake of water (Andrés et al. 2005, Gallart-Jornet et al. 2007b,c). However, Muratore et al. (2007) indicates brine-salted liquid-smoked salmon to have poorer sensorial qualities, as judged by a tasting panel. Moreover, the soluble component of the fillets can leach out during brine salting (Larsen et al. 2007). Thus, brining may have economic advantages such as increasing the yield but nutritional components are lost from the flesh during the process (Larsen et al. 2008).

Salting has a noticeable preservative effect. This is mainly due to the reduction in water activity and the consequent prevention of the growth of many spoilage microorganisms, along with the formation of a more membranous surface which further inhibits microorganism growth (Muratore et al. 2007, Frangos et al. 2010).

\section{Smoking}

Smoking is a centuries-old food preservation technique, but nowadays fish products are mainly smoked because of the attractive flavour and colour this process confers upon them (Guillen and Manzanos 1996). It is well known that smoking food enriches it in the aromatic compounds contained in the smoke. Processes of adhesion, condensation, 
Vol. 20(2011): 217-227.

diffusion and/or absorption occur between the food and the smoke. As a consequence, generally desirable changes occur in the colour, taste, texture and composition of the food. These changes vary depending on the composition of the smoke or smoke flavouring used, the composition of the food itself, and the conditions under which either type of smoking is undertaken (Toth and Potthast 1984) (Table 1).

The treatment of salmon with liquid smoke leads to changes in its physicochemical and sensorial attributes, depending on the composition of the liquid flavouring (and therefore on the type of wood originally used to produce it) (Toth and Potthast 1984). Guillén et al. (2005) reported liquid beech and oak flavours to generate different fish headspace compositions and, therefore, different flavours in salmon flesh. The headspace of salmon smoked with liquid oak smoke is richer in phenol derivatives than samples smoked with liquid beech smoke.

Little attention has been paid to the physicochemical attributes of fish treated with liquid smoke. Bugueño et al. (2003) reported that salmon treated in this way showed no significant changes in any of the chemical or physical variables they investigated $(\mathrm{pH}$, total volatile nitrogenous bases, etc.). However, Martinez et al. (2007a, 2009) reported changes in non-protein nitrogen, proteins, and in the fat and moisture contents. These authors used two liquid smokes of different composition to smoke salmon, one rich in phenolic compounds, the other rich in carbonyl compounds. The fish treated with the latter showed larger quantities of non-protein nitrogen and smaller quantities of protein (both sarcoplasmic and myofibrillar), fat and moisture.

It should be remembered that the sensorial attributes of a food are vital for consumer acceptance, and this may be no more true than with smoked foods. The following lines indicate the changes these attributes may undergo in salmon treated with liquid smoke.

The aroma and flavour of smoked foods are mainly owed to volatile compounds in the liquid smoke adhering to the flesh. Of special importance are phenolic compounds such as syringaldehyde and coniferaldehyde, which are strongly retained by food and intensify the aroma of smoked fish very well (Varlet et al. 2007b). Their adhesion also prevents them from being lost over time by evaporation (Guillén and Manzanos 1996)

The aroma of liquid-smoked salmon depends on the type of liquid smoke used, the surface composition of the fish, and the conditions under which the treatment is performed (Sérot et al. 2004). The volatile aldehydes responsible for the aroma of smoked fish are generated by two main pathways: the Maillard reaction (i.e., interactions between smoke carbonyl groups and food amino groups), which provides smoke aromas, and lipid oxidation, which provides fishy aromas (Varlet et al. 2007b). The compounds making up the aromatic profile of liquid-smoked salmon are different to those associated with traditional smoking; derivatives of pyridine have been detected, along with the products of lipid oxidation (Varlet et al. 2007c, 2007d). Cardinal et al. (1997) reported that, depending on the type of liquid smoke used, the products of lipid oxidation may be so abundant as to mask the product's own fishy odour.

Guaiacol and its derivatives have been described responsible for the 'smoked' taste and syringol and its derivatives for the smoked smell. Other compounds mainly associated with this smoke aroma and flavour include phenol, p-cresol, o-cresol, guaiacol, 4-memethyguaiacol, 4-ethyl guaiacol, eugenol, 4-propylguaiacol, and isoeugenol (Sérot and Lafficher 2003, Varlet et al. 2006, Varlet et al. 2007a). The final aroma of the salmon is, however, a product of a much more complex mix of compounds (Daun 1972, Maga 1987).

The taste of liquid-smoked salmon is also very different to that produced by the traditional technique, especially its in terms of the descriptor "salty" (Varlet et al. 2007c). This could mean that liquid smoke, as well as generating aromas, is involved in physical interactions that influence saltiness.

The conspicuous pink coloration of salmonid fish flesh is owed to carotenoid pigments, notably astaxanthin (3,3'-dihydroxi- $\beta, \beta$-carotene-4, $4^{\prime}$-dione) and canthaxantin ( $\beta, \beta$-carotene- $4,4^{\prime}$-dione), that the fish accumulate through their diet (Choubert et al. 2005, 


\section{AGRICULTURAL AND FOOD SCIENCE}

Martinez, O. et al. Liquid smoked salmon as affected by salting method

Rora et al. 2005, Webb et al. 2007). After smoking, the colour of fish flesh can vary depending on the pigments present, the quantity and composition of smoke deposits, and the interactions between these and the flesh (Sirkoski et al. 1998). However, the colour of the product is mainly due to Maillardtype reactions (Ruiter 1979). Oily fish commonly go browner because of a reaction between proteins or amino acids and the carbonyl derivatives of lipids. This reaction is influenced by the same factors that influence lipid oxidation (temperature, oxygen water activity, and the presence of oxidants and antioxidants). In salmon, non-enzymatic browning caused by Maillard-type reactions typically occurs at high water activities, while at low water activities browning is usually caused by the above protein-lipid derivative interactions. The two types of reaction can, in fact, inhibit one another.

Toth and Potthast (1984) and Cardinal et al. (2004) indicate colour development to depend mainly on carbonyls, while the flavour in their samples was largely owed to the type and quantity of phenolic compounds present. Martinez et al. (2007a) reported a strong colour intensity in salmon smoked with liquid smoke rich in carbonyl compounds. However, Daun (1972) indicate that certain high molecular weight phenols in the smoke vapour phase contribute to the colour of the product. These phenolic compounds would appear to have sufficient hydroxyl groups to be able to enter into lattices (via hydrogen bonding) with collagen at multiple sites. Volatile aldehydes such as coniferaldehyde and syringaldehyde give rise to orange colours in liquid-smoked fish (Clifford et al. 1980).

One of the most important quality characteristics of fish flesh is its muscle texture. In traditional hot-smoked foods, texture changes are mainly owed to the denaturing of proteins by heat (Gill et al. 1992), while in liquid-smoked fish it is mainly a consequence of the action of endogenous proteases hydrolysing the proteins more easily given the latters' salt-induced changes in conformation (Hansen et al. 1996, Lund and Nielsen 2001, Hultmann et al. 2004).

Some authors report an increase in the firmness of traditional cold-smoked fish (Sigurgisladottir et al. 2000. Birkeland et al. 2004) - an increase that is greater when the temperature reaches closer to $30{ }^{\circ} \mathrm{C}$ than $20^{\circ} \mathrm{C}$ (Gómez-Guillén et al. 2000, Hultmann et al. 2004).

The water content of fish flesh strongly influences its texture (Rongrong et al. 1998), with lower water contents producing firmer products. Montero et al. (2003) showed the water content of salmon fillets to be reduced after traditional cold smoking. Martinez et al. (2007a), working with salmon smoked with liquid smoke, reported a reduction in the water content and an increase in its hardness, fracturability and cohesiveness, especially if the liquid smoke was rich in carbonyl compounds. Thus, the components of the smoking liquid also influence the textural quality of smoked foods (Daun 1972, Sink and Hsu 1981). Hassan (1988) showed that smoking causes a reduction in flesh $\mathrm{pH}$, perhaps due to smoke acid absorption, a loss of moisture and the reaction of phenols, polyphenols and carbonyl compounds with proteins, SH groups and amino groups respectively.

Finally, it should be remembered that the one the major problems faced in the marketing and distribution of smoked seafoods is their perishability and hygiene, i.e., contamination by spoilage and pathogenic microorganisms. When foods are rejected on the grounds of their sensorial properties it is reasonable to assume them to be contaminated by both types. Nevertheless, it is no always true. Sometimes developing of off-odours or off-flavours occurs when hygienic quality is still between acceptable margins (Gomez-Guillén et al. 2009). Some other times, a product is accepted, attending to sensorial criteria even when spoilage bacterial growth is already too high (Jorgensen et al. 2001) or the product is not acceptable from a safety perspective (Gram 2001a, 2001b, Dressler 2005).

The initial bacterial load of fish living in temperate waters is dominated by Gram negative organisms - psycrophilic bacilli of the genera Pseudomonas, Alteromonas, Moraxella, Acinetobacter, Flavobacterium and Vibrio. However, after capture and handling, qualitative and quantitative changes in this initial flora can occur, and great variation in microorganisms and their numbers have been reported in salmon from different smoking facilities. This variability is due to differences in the 
Vol. 20(2011): 217-227.

raw material and processing variables (Hansen et al. 1998).

Generally, the vacuum packaging of smoked salmon inhibits the growth of Pseudomonas and favours the proliferation of Shewanella putrefaciens plus organisms such as Photobacterium phosphoreum, both of which are tolerant to $\mathrm{CO}_{2}$ and psychrotrophs (Gram et al. 2002). Lactic acid bacteria and members of Enterobacteriaceae are the largest group spoilage organisms affecting traditional cold-smoked salmon (Rachmana et al 2004, Gram and Huss 1996).

Authors working with liquid-smoked salmon that was later vacuum packed and stored refrigerated reported smoke concentrates to have a certain antibacterial action. A shelf-life of 25-45 days has been estimated for salmon processed this way (Table 2). Indeed, both the phenolic and carbonyl fractions show antimicrobial properties (Maga 1987, Painter 1998, Suñén 1998, Suñén et al. 2001, Suñén et al. 2003). However, liquid smokes with a low $\mathrm{pH}$ and a high carbonyl content are those with the greatest antimicrobial potential against both Gram negative and positive organisms (Milly et al. 2005). Martinez et al. (2005) reported that a liquid smoke flavouring rich in carbonyl compounds had greater antimicrobial activity than another rich in phenolic compounds.

With respect to pathogenic bacteria, the greatest risk is posed by the growth of Listeria monocytogenes (Gram 2001b, Ward 2001) since it can grow at low temperature and in high salt concentrations. However, good manufacturing practices and adequate storage can eliminate this risk (Autio et al. 1999, González-Rodríguez et al. 2002). Spoilage organisms can act as a barrier to the entry of possible pathogenic species (Giménez and Dalgaard 2004, Tome et al. 2006), and strains of Carnobacterium are being studied for their possible use as bioprotectors against Listeria monocytogenes in smoked salmon (Connil et al. 2002, Brillet 2004, Nilsson et al. 2004, Brillet et al. 2005).

Table 2. Shelf-life of smoked Atlantic salmon (Salmo salar) treated with liquid smoke flavourings.

\begin{tabular}{|c|c|c|c|c|}
\hline Authors & Smoking method & Storage coditions & Criteria & Shelf life \\
\hline $\begin{array}{l}\text { Martinez et al. } \\
(2010)\end{array}$ & $\begin{array}{l}\text { Liquid smoking: } \\
\text { Scansmoke, Broste A/S } \\
\text { (high phenolic content) }\end{array}$ & $\begin{array}{l}\text { vacuum-packed } \\
\text { refrigerated storage }\end{array}$ & sensory & 30 days \\
\hline $\begin{array}{l}\text { Bikerland and Skara } \\
(2008)\end{array}$ & $\begin{array}{l}\text { Liquid smoking (Smokez } 5096 \\
\text { Salmon Smoke) }\end{array}$ & $\begin{array}{l}\text { vacuum-packed } \\
\text { refrigerated storage }\end{array}$ & sensory & $<31$ days \\
\hline $\begin{array}{l}\text { Martinez et al. } \\
(2007 \mathrm{a}, \mathrm{b})\end{array}$ & $\begin{array}{l}\text { Liquid smoking: } \\
\text { a) Scansmoke, Broste } \mathrm{A} / \mathrm{S} \\
\text { (high phenolic content) } \\
\text { b) AFS-10 SOL, Amcan Ingredientes } \\
\text { (high carbonyl content) }\end{array}$ & $\begin{array}{l}\text { vacuum-packed } \\
\text { refrigerated storage }\end{array}$ & sensory & $\begin{array}{l}\text { a) } 32 \text { days in vacuum- } \\
\text { packed refrigerated } \\
\text { storage } \\
\text { b) } 45 \text { days in vacu- } \\
\text { um-packed refrigerated } \\
\text { storage }\end{array}$ \\
\hline $\begin{array}{l}\text { Bugueño et al. } \\
(2003)\end{array}$ & $\begin{array}{l}\text { Liquid smoking: } \\
5 \text { BF } 4046 \\
\text { (Taberner, S.A., Spain) }\end{array}$ & $\begin{array}{l}\text { a) vacuum-packed } \\
\text { refrigerated storage } \\
\text { b) modified atmosphere, } \\
\text { refrigerated storage }\end{array}$ & $\begin{array}{l}\text { microbial } \\
\text { growth }\end{array}$ & 25 days \\
\hline $\begin{array}{l}\text { Leroi and Joffraud } \\
(2000)\end{array}$ & $\begin{array}{l}\text { Cold smoked:a) } 2 \% \mathrm{NaCl}(\mathrm{w} / \mathrm{w}) \text { and } \\
0.8 \mathrm{mg} \text { phenols } / 100 \mathrm{~g} \text { or, } \\
\text { b) } 3 \% \mathrm{NaCl}(\mathrm{w} / \mathrm{w}) \text { and } 0.45 \mathrm{mg} \\
\text { phenols } / 100 \mathrm{~g}\end{array}$ & $\begin{array}{l}\text { vacuum-packed } \\
\text { refrigerated storage }\end{array}$ & sensory & 28 days \\
\hline
\end{tabular}


Martinez, O. et al. Liquid smoked salmon as affected by salting method

\section{Conclusion}

Dry salting is the best method for salting salmon to be liquid smoked; this technique reduces economic and nutritional losses. Dry salting and treatment with liquid smoke flavouring can help improve the physiochemical and sensorial characteristics of salmon better than dry or brine salting followed by traditional smoking. Autolytic deterioration and the growth of spoilage bacteria would appear to be similar in both types of product. The microbiological quality of salmon liquid-smoked with flavourings rich in carbonyl compounds would appear to better than that achieved with flavourings rich in phenolic compound.

\section{References}

Abu-Ali J.M. \& Barringer S. 2007. Colour and texture development of potato cylinders with liquid smoke during baking, frying and microwaving. Journal of food Processing and Preservation 31: 334-344.

Alfonso M.D. \& Sant'Ana. 2008. Effects of pretreatment with rosemary (Rosmarinus officinalis L.) in the prevention of lipid oxidation in salted tilapia fillets. Journal of Food Quality 31: 586-595.

Andrés A., Rodriguez-Barona S., Barat J.M. and Fito P. 2005. Salted cod manufacturing: influence of salting procedure on process yield and product characteristics. Journal of Food Engineering 69: 467-471.

Aubourg S. P. \& Ugliano M. 2002. Effect of brine pre-treatment on lipid stability of frozen horse mackerel (Trachurus trachurus). European Food Research and Technology 215: 91-95.

Aursand I.G., Veliyulen E. and Bocker U. 2009. Water and salt distribution in Atlantic salmon (Salmo salar) studied by low-field $\mathrm{H}-1 \mathrm{NMR}, \mathrm{H}-1$ and $\mathrm{Na}-23 \mathrm{MRI}$ and light microscopy: effects of raw material quality and brine salting. Journal of Agriculture and Food Chemistry 57:46-54.

Aursand I.G, Erikson U. and Veliyulin E. 2010. Water properties and salt uptake in Atlantic salmon fillets as affected by antemorten stress, rigor mortis and brine salting: a low-field $\mathrm{H}-1 \mathrm{NMR}$ and $\mathrm{H}-1 / \mathrm{Na}-23 \mathrm{MRI}$ study. Food Chemistry 120: 482-489.

Autio T., Hielm S., Miettinen M., Sjoberg A.M., Aarnisalo K., Bjorkroth J., Mattila-Sandholm T. and Korkeala H. (1999). Sources of Listeria monocytogenes contamination in a cold-smoked rainbow trout processing plant detected by pulsed-field gel electrophoresis typing. Applied and Environmental Microbiology 65: 150-155.
Bannerman A. \& Horne J. 2001. Recommendations for the production of smoked salmon. Aberdeen, Scotland: Torry Research Station, Ministry of Agriculture.

Barat J.M., Rodriguez-Varona S., Andres A. and Fito P. 2002. Influence of increasing brine concentration in the cod salting process. Journal of Food Science 65: 1922-1925.

Bellagha S., Sahli A., Farhat A., Kechaou N. and Glenza A. 2007. Studies on salting and drying of sardine (Sardinella aurita): experimental kinetics and modelling. Journal of Food Engineering 78: 947-952.

Birkeland S., Skara T., Bjerkeng B. and Rora A.M.B. 2003. Product yield and gaping in cold-smoked Atlantic salmon (Salmo salar) fillets as influenced by different injection-salting techniques. Journal of Food Science 68:1743-1748.

Birkeland S., Rora A.M., Skara T. and Bjerkeng, B. 2004. Effects of cold smoking procedures and raw material characteristics on product-yield and quality parameters of cold smoked Atlantic salmon (Salmo salar L.) fillets. Food Research International 27: 273-286.

Birkeland, S. \& Bjerkeng B. 2005. The quality of coldsmoked Atlantic salmon (Salmo salar) as affected by salting method, time and temperature. International Journal of Food Science and Technology 40:963-976.

Birkeland S. \& Skara T. 2008. Cold smoking of Atlantic salmon (Salmo salar) fillets with smoke condensate an alternative processing technology for the production of smoked salmon. Journal of Food Science 73: S326-S332.

Bocker, U.; Kohler, A.; Aursand, IG and Ofstad, R. 2008. Effects of brine salting with regard to raw material variation of Atlantic salmon (Salmo salar) muscle investigated by Fourier transform infrared microspectroscopy. Journal of Agricultural and Food Chemistry 56: 5129-5137.

Bras A. \& Costa R. 2010. Influence of brine salting prior to pickle salting in the manufacturing of various salted-dried fish species. Journal of Food Engineering 100: 490-495.

Brillet A. 2004. Biodiversity of Listeria monocytogenes sensitivity to bacteriocin-producing Carnobacterium strains and application in sterile cold-smoked salmon. Journal of Applied Microbiology 97: 1029-1037.

Brillet A., Pilet M.F., Prevost H., Cardinal M. and Leroi, F. 2005. Effect of inoculation of Carnobacterium divergens V41, a biopreservative strain against Listeria monocytogenes risk, on the microbiological, chemical and sensory quality of cold-smoke salmon. International Journal of Food Microbiology 104: 309-324.

Bugueño G., Escriche I., Martinez-Navarrete N., Camacho M.D.M. and Chiralt, A. 2003. Influence of storage conditions on some physical and chemical properties of smoked salmon (Salmo salar) processed by vacuum impregnation techniques. Food Chemistry 81: 85-90.

Cardinal M., Berdagué J.L., Dinel V., Knockaert C. and Vallet J.J. 1997. Effect of various smoking techniques on the nature of volatile compounds and on the sensory characteristics of salmon meat. Science des Aliments 17: 679-696.

Cardinal M., Knockaert C., Torrissen O., Sigurgisladottir S., Morkore T., Thomassen M. and Vallet J.L. 2001. Relation of smoking parameters to the yield, color and sensory quality of smoked Atlantic salmon (Salmo salar). Food Research International 34: 537-550. 
Vol. 20(2011): 217-227.

Cardinal M., Gunnlaugsdottir H., Bjoernevik M., Ouisse A., Vallet J.L. and Leroi F. 2004. Sensory characteristics of cold smoked Atlantic salmon (Salmo salar) from European market and relationships with chemical, physical and microbiological measurements. Food Research International 37: 181-193.

Carton I., Bocker U., Ofstad R, Sorheim O and Kohler A. 2009. Monitoring secondary structural changes in salted and smoked salmon muscle myofiber proteins by FTIR microspectroscopy. Journal of Agriculture and Food Chemistry 57: 3563-3570.

Clifford M.N., Tang S.L. and Eyo A.A. 1980. Smoking of foods. Process Biochemistry (June/July): 8-11.

Connil N., Prevost H. and Dousset X. 2002. Production of biogenic amines and divercin V41 in cold smoked salmon inoculated with Carnobacterium divergens V41, and specific detection of this strain by multiplex-PCR. Journal of Applied Microbiology 92: 611-617.

Choubert G., Dentella E., Atgie C. and Baccaunaud M. 2005. Effect of light on colour stability of sliced smoked rainbow trout (Orcorhynchus mykiss) fed astaxanthin. Food Research International 38, 949-952.

Czerner M. \& Yeannes M.I. 2010. Brining kinetics of different cuts of anchovy (Engraulis anchoita). International Journal of Food Science and Technology 45: 2001-2007.

Daun, H. 1972. Sensory properties of phenolic compounds isolated from curing smoke as influenced by its generation parameters. Lebensmittel-Wissenschaft und-Technologie 5, 102-5.

Dondero M., Cisternas F., Carvajal L. and Simpson, R. 2004. Changes in quality of vacuum-packed coldsmoked salmon (Salmo salar) as a function of storage temperature. Food Chemistry 87: 543-550.

Dressler D. 2005. Botulism caused by consumption of smoked salmon. Nervenart 76: 763-766.

Frangos L., Pyrgotou N., Giatracou V., Ntzimani A. and Savvaidis I.N. 2010. Combined effects of salting, oregano oil and vacuum-packaging on the shelf-life of refrigerated trout fillets. Food Microbiology 27: 115-121.

Gallart-Jornet L., Rustad T., Barat J.M., Fito P. and Escriche I. 2007a. Effect of superchilled storage on the freshness and salting behaviour of Atlantic salmon (Salmo salar) fillets. Food Chemistry 103: 1268-1281.

Gallart-Jornet L., Barat J.M., Rustad T., Erikson U. and Escriche I. 2007b. Influence of brine concentration of Atlantic salmon fillet salting. Journal of Food Engineering, 80: 267-275.

Gallart-Jornet L., Barat J.M, Rustad T., Erikson U., Escriche I. and Fito P. 2007c. A comparative study of brine salting of Atlantic cod (Gadus morhua) and Atlantic salmon (Salmo salar). Journal of Food Engineering 79: 261-270.

Gedela S., Gamble R.K., Macwana S., Escoubas J.R. and Muriana P.M. 2007. Effect of inhibitory extracts derived from liquid smoke combined with postprocess pasteurization for control of Listeria monocytogenes on readyto-eat meats. Journal of Food Protection 70: 2749-2756.

Gill T.A., Chan J.K., Phonchareon K.F. and Paulson A.T. 1992. Effect of salt concentration and temperature on heat-induced aggregation and gelation of fish myosin. Food Research International 25: 333-341.

Giménez B. \& Dalgaard P. 2004. Modelling and predicting the simultaneous growth of Listeria monocytogenes and spoilage micro-organisms in cold-smoked salmon. Jour- nal of Applied Microbiology, 96, 96-109.

Gómez-Guillén M.C., Montero P., Hurtado O. and Borderías, A.J. 2000. Biological characteristics affect the quality of farmed Atlantic salmon and smoked muscle. Journal of Food Science 65: 53-60.

Gómez-Guillén M.C., Gómez-Estaca J., Gimenez B. and Montero P. 2009. Alternative fish species for cold-smoking process. International Journal of Food Science and Tchnology 44: 1525-1535.

González-Rodríguez M.N., Sanz J.J., Santos J.A., and Garcia, M.L. 2002. Numbers and types of microorganisms in vacuum-packed cold-smoked freshwater fish at the retail level. International Journal of Food Microbiology 77: 161-168.

Goulas A.E. \& Kontominas M.G. 2005. Effect of salting and smoking-method on the keeping quality of chub mackerel (Scomber japonicus): biochemical and sensory attributes. Food Chemistry 93: 511-520.

Goulas A.E. \& Kontominas M.G. 2007. Combined effect of light salting, modified atmosphere packaging and oregano essential oil on the shelf-life of sea bream (Sparus aurata): Biochemical and sensory attributes. Food Chemistry 100: 287-296.

Gram L.; \& Huss H.H. 1996. Microbiological spoilage of fish and fish products. International Journal of Food Microbiology 33: 121-37.

Gram L. 2001a. Potential hazards in cold-smoked fish: Clostridium botulinum type E. Journal of Food Science 66: S1082-S1087.

Gram L. 2001b. Potential hazards in cold-smoked fish: Listeria monocytogenes. Journal of Food Science 66: S1072-S1081.

Gram L., Ravn L., Rasch M., Bruhn J. B., Christensen A. B. and Givskov M. 2002. Food spoilage-interactions between food spoilage bacteria. International Journal of Food Microbiology 78: 79-97.

Guillén, M.D. \& Manzanos, M.J. 1996. Study of the components of a solid smoke flavoring preparation. Food Chemistry, 55, 251-7.

Guillén M.D., Ruiz A. and Cabo N. 2004. Study of the oxidative degradation of farmed salmon lipids by means of Fourier transform infrared spectroscopy. Influence of salting. Journal of the Science of Food and Agriculture 84: 1528-1534.

Guillén M.D., Carton I., Casas C. and Salmeron J. 2005. Changes in the headspace of farmed salmon by salting, smoking and both combined processes. Proceedings of Intrafood 2005. Valencia. pp. 105-108.

Hansen L.T., Gill T., Røentved S.D. and Huss H.H. 1996. Importance of autolysis and microbiological activity on quality of cold-smoked salmon. Food Research International 29: 181-188.

Hansen L.T., Røntved S. and Hans H.H. 1998. Microbiological quality and shelf life of cold-smoked salmon from three different processing plants. Food Microbiology 15: 137-150.

Hassan I.M. 1988. Processing of smoked common carp fish and its relation to some chemical, physical and organoleptic properties. Food Chemistry 27: 95-106.

Hatae K.., Sakamoto H., Shimada A., Matsumoto M., Yamanaka H. and Watabe S. 1990. Physical-properties of arai made by applying of thaw-rigor. Nippon Suisan Gakkaishi 56: 2113-2118. 


\section{AGRICULTURAL AND FOOD SCIENCE}

Martinez, O. et al. Liquid smoked salmon as affected by salting method

Huang Y., Cavinato A.G., Mayes D.M., Bledsoe G.E. and Rasco B. A. 2002. Nondestructive prediction of moisture and sodium chloride in cold smoked Atlantic salmon (Salmo salar). Journal of Food Science 67: 2543-2547.

Hultmann L. \& Rustad T. 2004. Iced storage of Atlantic salmon (Salmo salar) - effects on endogenous enzymes and their impact on muscle proteins and texture. Food Chemistry 87: 31-41.

Hultmann L., Røra A.M.B., Steinsland I., Skara T. and Rustad T. 2004. Proteolytic activity and properties of proteins in smoked salmon (Salmo salar) - effects of smoking temperature. Food Chemistry 85: 377-387.

Johnston J.A., Li X., Vieira V.L.A., Nickell D., Dingwall A., Alderson R., Campbell P. and Bickerdike R. 2006. Muscle and flesh quality traits in wild and farmed Atlantic salmon. Aquaculture 256: 323-336.

Jorgensen L.V. Huss H.H. and Dalgaard D. 2001. Significance of volatile compound produced by spoilage bacteria in vacuum-packed cold-smoked salmon (Salmo salar) analyzed by GC-MS and multivariate regression. Journal of Agricultural and Food Chemistry 49: 2376-2381.

Kashiri H., Haghparast S. and Shabanpour B. 2011. Effects of sodium salt solutions (sodium acetate, lactate and citrate) on physicochemical and sensory characteristics of Persian sturgeon (Acipenser persicus) fillets under refrigerated storage. Journal of Agriculture, Science and Technology 13: 89-98.

Kristinsson H.G., Crynen S. and Yagiz Y. 2008. Effect of filtered wood smoke treatment compared to various gas treatments on aerobic bacteria in yellowfin tuna steaks. LWT-Food Science and Technology 41: 963-976.

Larsen R., Stormo S.K., Dragnes B.T. and Elvevoll E. 2007. Losses of taurine, creatine, glycine and alanine from cod (Gadus morhua) fillet during processing. Journal of Food Composition and Analysis 20: 396-402.

Larsen R., Olsen S.H., Kristoffersen S. and Elvevoll, E.O. 2008. Low salt brining of pre-rigor filleted farmed cod (Gadus morhua L.) and the effect on different quality parameters. LWT-Food Science and Technology 41: 1167-1172.

Leroi F. 2010. Occurrence and role of lactic acid bacteria in seafood products. Food Microbiology 27: 698-709.

Leroi F. \& Joffraud J.J. 2000. Salt ad smoke simultaneously affect chemical and sensory quality of cold-smoked salmon during $5^{\circ} \mathrm{C}$ storage predicted using factorial design. Journal of Food Protection 63: 1222-1227.

Lund K.E. \& Nielsen H.H. 2001. Proteolysis in salmon (Salmo salar) during cold storage; effects of storage time and smoking process. Journal of Food Biochemistry 25: $379-395$.

Maga J. A. 1987. The flavour chemistry of wood smoke. Food Review International 3, 139-183.

Martinez O., Casas C., Guillen M.D. and Salmeron J. 2005. Microbiological changes of salmon treated with two liquid smoke flavourings. 2nd International Congress of Self-Control and Food Safety, Bilbao, Spain. pp. 193.

Martinez O., Salmeron J., Guillen M.D. and Casas C. 2007a. Textural and physicochemical changes in salmon (Salmo salar) treated with commercial liquid smoke flavourings. Food Chemistry 100: 498-503.

Martinez O., Salmeron J., Guillen M.D. and Casas C. 2007b. Sensorial and physicochemical characteristics of salmon (Salmo salar) treated by different smoking processes during storage. Food Science and Technology International 13: 477-484.

Martinez O., Salmeron J., Guillen M.D. and Casas C. 2009. Textural and physicochemical characteristics of salmon (Salmo salar) treated by different smoking processes during storage. Alimentaria 399: 92-97.

Martinez O., Salmeron J., Guillen M.D. and Casas C. 2010. Effect of freezing on the physicochemical, textural and sensorial characteristics of salmon (Salmo salar) smoked with a liquid smoke flavouring. LWT-Food Science and Technology, 43: 910-918.

Milly P.J., Toledo R.T. and Ramakrishnan S. 2005. Determination of minimum inhibitory concentrations of liquid smoke fractions. Journal of Food Science 70: 12-17.

Minh V.N, Thorarinsdottir K.A, Gudmundsdottir A., Thorkelsson G. and Arason S. 2011. The effect of salt concentration on conformational changes in cod (Gadus morhua) proteins during brine salting. Food Chemistry 125: 1013-1019.

Montero P., Gómez-Guillén M.C. and Borderias A.J. 2003. Influence of salmon provenance and smoking process on muscle functional characteristics. Journal of Food Science 68: 1155-1160.

Morkore T., Ruohonen K., and Kiessling A. 2009. Variation in texture of farmed Atlantic salmon (Salmo salar L.). Relevance of muscle fiber cross-sectional area. Journal of Texture Studies 40: 1-15.

Muratore G., Mazzaglia A., Lanza C.M. and Licciardello F. 2007. Effects of process variable on the quality of swordfish fillets flavoured with smoke condensate. Journal of Food Processing and Preservation 31: 167-177.

Nilsson L., Ng Y.Y., Christiansen J.N., Jorgensen B.L., Grotinum D. and Gram L. 2004. The contribution of bacteriocin to inhibition of Listeria monocytogenes by Carnobacterium piscicola strains in cold-smoked salmon systems. Journal of Applied Microbiology 96: 133-143.

Oehlenschlager, J. 2007. Water, fat and salt content in commercially traded $200 \mathrm{~g}$ consumer packages of cold smoked salmon (Salmo salar). Deutsche Lebensmittelrundschau 103: 569-573.

Painter T.J. 1998. Carbohydrate polymers in food preservation: an integrated view of the Maillard reaction with special reference to discoveries of preserved foods in Sphagnum-dominated peat bogs. Carbohydrate Polymers 36: 335-347.

Pszczola D.E. 1995. Tour highlights production and uses of smoke-based flavours. Food Technology 49: 70-74.

Rachmana C., Fourriera A., Sya A., De La Cochetiereb M.F., Prevosta H. and Xavier D. 2004. Monitoring of bacterial evolution and molecular identification of lactic acid bacteria in smoked salmon during storage. Le Lait 84 : 145-154.

Rongrong L., Carpenter J.A. and Cheney R. 1998. Sensory and instrumental properties of smoked sausage made with mechanically separated poultry (MSP) meat and wheat protein. Journal of Food Science 63: 923-929.

Rora A.M., Furukang R., Fjaera S. and Skjervold, P. 2004. Salt diffusion in pre-rigor filleted Atlantic salmon. Aquaculture 232: 201-211.

Rora A.M.B., Birkeland S., Hultmann L., Rustad T., Skara T. and Bjerkeng, B. 2005. Quality characteristics of farmed Atlantic salmon (Salmo salar) fed diets high in soybean or fish oil as affected by cold-smoking tempera- 
Vol. 20(2011): 217-227.

ture. Food Science and Technology/Lebensmittel-Wissenschaft und-Technologie 38: 201-211.

Ruiter A. (1979). Color of smoked foods. Food Technology 33: 54-63.

Sannaveerappa T., Ammu K. and Joseph J. 2004. Protein related changes during salting of milkfish (Chanos chanos). Journal of Science and Food Agriculture 84: 863-869.

Serot T. \& Lafficher C. 2003. Optimisation of solid-phase microextraction coupled to gas chromatography for determination of phenolic compounds in smoked herring. Food Chemistry 82: 513-519.

Sérot T., Baron R., Knockaert C. and Vallet J. L. 2004. Effect of smoking processes on the contents of 10 major phenolic compounds in smoked fillets of herring (Cuplea harengus). Food Chemistry 85: 111-120.

Sigurgisladottir S., Sigurdardottir M.S., Torrissen O., Vallet J.L. and Hafsteinsson H. 2000. Effects of different salting and smoking processes on the microstructure, the texture and yield of Atlantic salmon (Salmo salar) fillets. Food Research International 33: 847-855.

Sink J.D. \& Hsu, L.A. (1977). Chemical effect of smokeprocessing on frankfurter manufacture and storage characteristics. Journal of Food Science 42: 1489.

Sirkoski Z., Haard N., Motohiro T. and Sin Pan, B. 1998. Fish drying and smoking. Production and quality. In: Quality. J. Doe (Ed.). CRC Press. Miami. pp. 250.

Smith G. \& Hole M. 1991. Browning of salted sun-dried fish. Journal of the Science of Food and Agriculture 55: 291-301.

Suñén E. 1998. Minimum inhibitory concentration of smoke wood extracts against spoilage and pathogenic microorganisms associated with foods. Letters in Applied Microbiology 27: 45-48.

Suñén E., Fernández-Galian B. and Aristimuno C. 2001. Antibacterial activity of smoke wood condensates against Aeromonas hydrophila, Yersinia enterocolitica and Listeria monocytogenes at low temperature. Food Microbiology 18: 387-393.

Suñén E., Aristimuño C. and Fernández-Galian B. 2003. Activity of smoke wood condensates against Aeromonas hydrophila and Listeria monocytogenes in vacuum-packaged, cold-smoked rainbow trout stored at $4^{\circ} \mathrm{C}$. Food Research International 36: 111-116.

Thiansilakul Y., Benjakul S. and Richards M.P. 2010. Changes in heme proteins and lipids associated with off-odour or seabass (Lates calcarifer) and red tilapia (Oreochromis mossambicus $x$ o. niloticus) during iced storage. Food Chemistry 121: 1109-1119.

Thorarinsdottir K.A., Arason S., Bogason S. and Krist- bergsson K. 2004. The effect of various salt concentratrions during brine curing of cod. International Journal of Food Science and Technology 39: 79-89.

Tome E., Teixeira P. and Gibbs P. A. 2006. Anti-listerial inhibitory lactic acid bacteria isolated from commercial cold smoked salmon. Food Microbiology 23: 399-405.

Toth L. \& Potthast K. 1984. Chemical aspects of the smoking of meat and meat products. Advances in Food Research 29: 87-158.

Underwood G. \& Shoop J. 2007. "Raw materials for flavourings: smoke flavourings. Nature, preparation and application", in: flavourings production, composition, application and regulations ( $2^{\text {nd }}$ edition). Ziegler. WileyVCH Verlag GmbH \& Co. KGaA, Weinheim, Germany. p. 289-308.

Unlusayin M., Erdilal R., Gumus B. and Gulyavuz H. 2010. The effects of different salting methods on extract loss from rainbow trout. Pakistan Veterinary Journal 30: 131-134.

Varlet V., Knockaert C., Prost C. and Serot T. 2006. Comparison of Odor-Active Volatile Compounds of Fresh and Smoked Salmon. Journal of Agricultural and Food Chemistry 54: 3391-3401.

Varlet V., Prost C. and Serot, T. 2007a. New procedure for the study of odour representativeness of aromatic extracts from smoked salmon. Food Chemistry 100: 820-829.

Varlet V., Prost C. and Serot, T. 2007b. Volatile aldehydes in smoked fish: Analysis methods, occurrence and mechanisms of formation. Food Chemistry 105: 1536-1556.

Varlet V., Serot T., Knockaert C., Cornet J., Cardinal M., Monteau F., Le Bizec B. and Prost C. 2007c. Organoleptic characterization and PAH content of salmon (Salmo salar) fillets smoked according to four industrial smoking techniques. Journal of the Science of Food and Agriculture 87: 847-854.

Varlet V., Serot T., Cardinal M., Knockaert C. and Prost C. 2007d. Olfactometric determination of the most potent odor-active compounds in salmon muscle (Salmo salar) smoked by using four smoke generation techniques. Journal of Agricultural and Food Chemistry 55: 4518-25.

Ward D.R. 2001. Description of the situation. Journal of Food Science 66: 1067-1071.

Webb J., Verspoor E., Aubin-Horth N., Romakkaniemi A. and Amiro, P. 2007. The Atlantic Salmon: genetics, conservation and management. In: The Atlantic salmon. Verspoor, Stradmeyer \& Nielsen (Eds). Blackwell Publishing. London. pp. 17-56.

Yanar Y., Celik M. and Akamca E. 2006. Effects of brine concentration on shelf-life of hot-smoked tilapia (Oreochromis niloticus) stored at $4^{\circ} \mathrm{C}$. Food Chemistry 97: 244-247. 